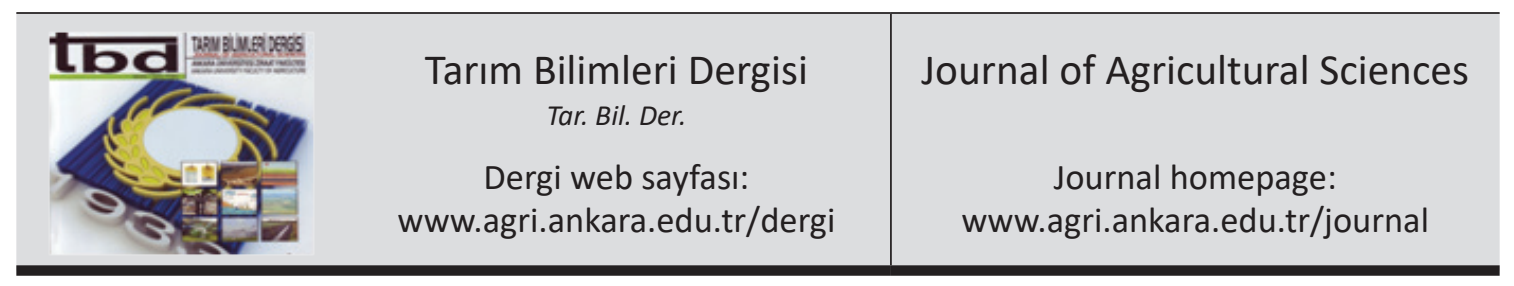

\title{
Economical Analysis of Chamomile (Matricaria recutita L.) Cultivars, Flower Yields Which are Obtained from Different Sowing Times and Row Spacing
}

\author{
Doğan ARSLAN ${ }^{a}$, Önder Volkan BAYRAKTAR ${ }^{\mathrm{b}}$, Mükremin TEMEL ${ }^{\mathrm{c}}$, Emine BAYRAM ${ }^{\mathrm{d}}$ \\ ${ }^{a}$ Siirt University, Faculty of Agriculture, Department of Field Crops, Kezer Campus, 56100, Siirt, TURKEY

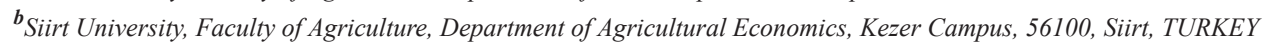

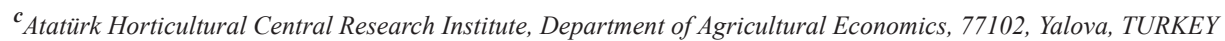 \\ ${ }^{d}$ Ege University, Faculty of Agriculture, Department of Field Crops, 35100 Bornova, İmir, TURKEY
}

\section{ARTICLE INFO}

Research Article DOI: 10.15832/ankutbd.300321

Corresponding Author: Doğan ARSLAN, E-mail: doganarslan@siirt.edu.tr, Tel: +90 (505) 6697315

Received: 22 September 2017, Received in Revised Form: 21 March 2018, Accepted: 04 April 2018

\begin{abstract}
This study was conducted with split-split plots experimental design based on four replications in the ecological conditions of Yalova in the area of Ataturk Central Horticultural Research Institute in growing seasons of 2008-2009 and 2010-2011.

In the study three chamomile (Matricaria recutita L.) cultivars (Bona, Bodegold and Zloty Lan) and a genotype, which was collected from the flora of Yalova Province, were used as material. There were four cultivars/genotypes, three sowing time (early November, early October, end of October) and four rows spacing $(15 \mathrm{~cm}, 30 \mathrm{~cm}, 45 \mathrm{~cm}, 60$ $\mathrm{cm}$ ). Sowing times were constructed to main plots, cultivars/genotypes to sub plots and row spacing to sub-sub plots.

The highest gross profit was calculated as $8818.33 € \mathrm{ha}^{-1}$ in first time of Zloty Lan cultivar at $15 \mathrm{~cm}$ row spacing. Although the Yalova genotype has the lowest cost, the gross profit among the cultivars/genotypes has been the lowest genotype.

Keywords: Chamomile; Matricaria recutita L.; Economical analysis; Gross profit; Sowing time; Row spacing
\end{abstract}

(C) Ankara Üniversitesi Ziraat Fakültesi

\section{Introduction}

Medicinal and aromatic plants are used as healing, medicine, food and condiment for centuries. For this reason, the cultivation of certain plants such as cumin, poppy, anise have been ongoing from prehistoric ages. Essential oils and aromatic extracts were used widely as the source of aromatic chemicals, as the starting synthesis material of natural identical or semi-synthesized aromatic chemicals, as perfumes by smell and flavor industries, for the composition of food additives, cleaning products, cosmetics and pharmaceuticals (Güngör et al 2005; Bayram et al 2010).

Although more than $40 \%$ of drugs, which were listed in the beginning of the $20^{\text {th }}$ century, were herbal origin, this ratio was decreased further than $5 \%$ in the middle of the 1970s. However, especially after 
the 1990s, the discovery of new areas of medicinal and aromatic plants, and the increasing demand for natural products increased the volume of use of these plants day by day (Bayram et al 2010). One of the plants, chamomile (Matricaria recutita L.), (Syn. M. chamomilla), has been using as folk medicine in Turkey and the World since ancient times. Thoughts on the power of treating are based on phytotherapy and ancient scientific studies, which was described by Hippocrates, Plinius, Dioscorides and Galen. These were also known by "Chamaemelon" who was known as Plinius, Dioscorides and Arabian doctors. The chamomile oil which was known as blue oil and important even today was discussed first time in 1588 (Gül 1995; Ceylan 1996). A famous Slovak proverb says: "An individual should always bow before the curative powers of the chamomile flower tea" (Salamon 2004).

Despite the growth of the world market, it is difficult to find chamomile's production values worldwide. Because, chamomile is cultivated on a small scales and statistics are not given by separating other medicinal and aromatic plants. Today these plants are produced in countries with low labor costs and are exported to industrialized countries.

Although there have been about agronomic studies of chamomile on agriculture, there has not been much work on the economic analysis of camomile farming.

In this study, the effects of different sowing times and different row spacing on total cost, gross profit and net profit were investigated in chamomile cultivars/genotypes and the result was tried to

\begin{tabular}{|c|c|}
\hline Sowing time & 2008-2009 growing season \\
\hline 1. Sowing time & nber 2008 \\
\hline 2. Sowing time & 02 December 2008 \\
\hline 3. Sowing time & 26 December 2008 \\
\hline
\end{tabular}

It was planned $15 \mathrm{~cm}, 30 \mathrm{~cm}, 45 \mathrm{~cm}$ and $60 \mathrm{~cm}$ as row spacing.

The trail was established in 2008-2009 and 2010-2011 growing seasons. Sowing lines was determine the highest gross profit. Thus, it is aimed to contribute to world literature on economical analysis of chamomile farming.

\section{Material and Methods}

\subsection{Material}

In this study, the data obtained from the study which was carried out according to with split-split plots experimental design based on four replications in the ecological conditions of Yalova in the area of Atatürk Central Horticultural Research Institute in growing seasons of 2008-2009 and 2010-2011 were used as material.

\subsection{Method}

The data obtained from the field research below is analyzed according to the gross margin analysis method.

The field research was conducted with split-split plots experimental design based on four replications in the ecological conditions of Yalova in the area of Ataturk Central Horticultural Research Institute in growing seasons of 2008-2009 and 2010-2011. In the study, there were four cultivars/genotypes, three sowing time and four rows spacing. Sowing times were constructed to main plots, cultivars to sub plots and row spacing to sub-sub plots.

The groups were classified as; Cultivars/ genotypes: Bona, Bodegold, Zloty Lan, Yalova

Sowings times are done in three different times. Sowing dates are presented as in following:

2010-2011 growing season

10 November 2011

30 November 2011

23 December 2011

prepared in a way to prevent seeds from flying from the winds. $1.5 \mathrm{~g}$ seeds were used in each parcel by calculating $278 \mathrm{~g}$ seeds in each ha ${ }^{-1}$. All seed quantities were calculated one by one for all 
distances between rows. The amount of seed in each rows seed was weighted in 0.0001 sensitivities due to the number of sowing rows. The weighed seeds were mixed with fine wood flour and then packed ready for planting. In both two seasons, $60 \mathrm{~kg} \mathrm{~N}, 40$ $\mathrm{kg} \mathrm{P}_{2} \mathrm{O}_{5}$ and $40 \mathrm{~kg} \mathrm{~K}_{2} \mathrm{O}$ were given to $\mathrm{ha}^{-1}$ according to Johri et al (1991). Also, fertilizers including phosphorus and potassium was given to soil before sowing. Nitrogenous fertilizer was given $40 \mathrm{~kg} \mathrm{ha}^{-1}$ before sowing and remaining amount was given one month after the emergence. $26 \%$ ammonium nitrate was used for the remaining $20 \mathrm{~kg} \mathrm{ha}^{-1}$ nitrogenous fertilizer. The necessary maintenance and irrigation procedures from the planting stage have been carried out until harvesting time. Any disease was not observed in the trail; however, aphid pest was found at the beginings of april and may in both two seasons, against to this, a chemical struggle was carried out with an agricultural drug including diazinon-acting substance. With this chemical struggle, plant was prevented from negative effects of this pest.

Gross profit, which is suitable to compare profitability of companies, was used to make economic analysis. Gross profit was calculated by using the formula;

Gross profit $=$ Gross production value-Variable costs (1)

Gross margin $=$ Total production-Indirect costs

When the sum of the gross margins of the company's production is equal to the indirect costs, it is in dead or is operating breakeven or zero point (Karagölge 2001). Gross profit in the short-term value of agriculture products can be an important benchmark criterion. The data related to four chamomile cultivar/genotypes was coded into computer in terms of production cost, row spacing and cultivars to analyse them with different time and sowing distances. Then variable costs (seed bed preparation, sowing, irrigation, weed control, pest control, fertilizer, labor costs) and total production costs were calculated with respect to groups. In addition to gross margin analysis techniques, simple percent calculations were done during analysis.
The gross profit per hectare has been calculated by multiplication of yield by price by attempting to sell wholesale to the herbalists in Turkey. Kruskal Wallis test was also used to identify statistically different groups by using some sample of data. The Kruskal-Wallis test is a non-parametric method for testing whether samples originate from the same distribution. It is used for comparing two or more independent samples of equal or different sample sizes (Kruskal \& Wallis 1952).

\section{Results and Discussion}

Table 1 demonstrates the data obtained from different chamomile cultivar productions used in the study. The costs related to tillage, fertilizing, spraying and watering for all independent variables which were chamomile cultivars, sowing times, and row spacing were calculated equal to each other. Additionally; variable expenses, which were sowing costs and seed expenses for Bodegold, Bona and Zloty Lan, were $769.23 € \mathrm{ha}^{-1}$ for each one. Seed expense for Yalova genotype population was $316.74 € \mathrm{ha}^{-1}$. The seed costs of foreign cultivars were higher than that of domestic genotype, because foreign cultivars of chamomile seed were imported from outside countries and they include Chamazulene in essential oil.

According to Table 1, the minimum maintenance costs are seen with $4.42 \%$ at second sowing time of Bodegold cultivar at $60 \mathrm{~cm}$ row spacing, and maximum one is seen with $17.27 \%$ at second sowing time of Yalova genotype at $15 \mathrm{~cm}$ row spacing. Another cost, harvesting and marketing costs, for first sowing time of Bodegold cultivar at $60 \mathrm{~cm}$ row spacing were found as minimum with $13.26 \%$, while the maximum one was second sowing time of Yalova population at $15 \mathrm{~cm}$ row spacing with $25.90 \%$. In this study, all of the harvests were made by hand. Manual harvesting is more costly in terms of time and energy than machine harvesting (Stričík $\&$ Salamon 2007). But for one ha and less, manual harvest is more profitable than machine harvest. On the other hand, for higher production areas, machine harvest is more profitable than manual harvest (Ivanović at al 2014). It is thought that the ratio of 
Table 1- Variable costs and ratios for groups $\left(€ \mathrm{ha}^{-1}, \%\right)$

\begin{tabular}{|c|c|c|c|c|c|c|c|c|c|c|}
\hline \multirow[t]{2}{*}{ Sowing time } & \multirow[t]{2}{*}{ Cultivars } & \multirow{2}{*}{$\begin{array}{c}\text { Row } \\
\text { spacing } \\
(\mathrm{cm})\end{array}$} & \multicolumn{2}{|c|}{$\begin{array}{l}\text { Maintenance } \\
\text { costs }\end{array}$} & \multicolumn{2}{|c|}{$\begin{array}{l}\text { Harvesting and } \\
\text { marketing costs }\end{array}$} & \multicolumn{2}{|c|}{$\begin{array}{l}\text { Other variable } \\
\text { costs }\end{array}$} & \multicolumn{2}{|c|}{$\begin{array}{c}\text { Total variable } \\
\text { costs }\end{array}$} \\
\hline & & & EUR & $\%$ & EUR & $\%$ & EUR & $\%$ & EUR & $\%$ \\
\hline \multirow{17}{*}{ I. Time } & \multirow{4}{*}{ Bodegold } & 15 & 361.99 & 13.72 & 542.99 & 20.58 & 1733.71 & 65.70 & 2638.69 & 100.00 \\
\hline & & 30 & 271.49 & 11.12 & 452.49 & 18.53 & 1717.42 & 70.35 & 2441.40 & 100.00 \\
\hline & & 45 & 181.00 & 8.07 & 361.99 & 16.13 & 1701.13 & 75.80 & 2244.12 & 100.00 \\
\hline & & 60 & 90.50 & 4.42 & 271.49 & 13.26 & 1684.84 & 82.31 & 2046.83 & 100.00 \\
\hline & \multirow{4}{*}{ Bona } & 15 & 361.99 & 13.72 & 542.99 & 20.58 & 1733.71 & 65.70 & 2638.69 & 100.00 \\
\hline & & 30 & 271.49 & 11.12 & 452.49 & 18.53 & 1717.42 & 70.35 & 2441.40 & 100.00 \\
\hline & & 45 & 181.00 & 8.07 & 361.99 & 16.13 & 1701.13 & 75.80 & 2244.12 & 100.00 \\
\hline & & 60 & 90.50 & 4.42 & 271.49 & 13.26 & 1684.84 & 82.31 & 2046.83 & 100.00 \\
\hline & \multirow{4}{*}{ Zloty Lan } & 15 & 361.99 & 13.72 & 542.99 & 20.58 & 1733.71 & 65.70 & 2638.69 & 100.00 \\
\hline & & 30 & 271.49 & 11.12 & 452.49 & 18.53 & 1717.42 & 70.35 & 2441.40 & 100.00 \\
\hline & & 45 & 181.00 & 8.07 & 361.99 & 16.13 & 1701.13 & 75.80 & 2244.12 & 100.00 \\
\hline & & 60 & 90.50 & 4.42 & 271.49 & 13.26 & 1684.84 & 82.31 & 2046.83 & 100.00 \\
\hline & \multirow{5}{*}{ Yalova } & 15 & 361.99 & 17.27 & 542.99 & 25.90 & 1191.18 & 56.83 & 2096.15 & 100.00 \\
\hline & & 30 & 271.49 & 14.30 & 452.49 & 23.83 & 1174.89 & 61.87 & 1898.87 & 100.00 \\
\hline & & 45 & 181.00 & 10.64 & 361.99 & 21.27 & 1158.60 & 68.09 & 1701.58 & 100.00 \\
\hline & & 60 & 90.50 & 6.02 & 271.49 & 18.05 & 1142.31 & 75.94 & 1504.30 & 100.00 \\
\hline & & 15 & 361.99 & 13.72 & 542.99 & 20.58 & 1733.71 & 65.70 & 2638.69 & 100.00 \\
\hline \multirow{14}{*}{ II. Time } & \multirow{3}{*}{ Bodegold } & 30 & 271.49 & 11.12 & 452.49 & 18.53 & 1717.42 & 70.35 & 2441.40 & 100.00 \\
\hline & & 45 & 181.00 & 8.07 & 361.99 & 16.13 & 1701.13 & 75.80 & 2244.12 & 100.00 \\
\hline & & 60 & 90.50 & 4.42 & 271.49 & 13.26 & 1684.84 & 82.31 & 2046.83 & 100.00 \\
\hline & \multirow{4}{*}{ Bona } & 15 & 361.99 & 13.72 & 542.99 & 20.58 & 1733.71 & 65.70 & 2638.69 & 100.00 \\
\hline & & 30 & 271.49 & 11.12 & 452.49 & 18.53 & 1717.42 & 70.35 & 2441.40 & 100.00 \\
\hline & & 45 & 181.00 & 8.07 & 361.99 & 16.13 & 1701.13 & 75.80 & 2244.12 & 100.00 \\
\hline & & 60 & 90.50 & 4.42 & 271.49 & 13.26 & 1684.84 & 82.31 & 2046.83 & 100.00 \\
\hline & \multirow{4}{*}{ Zloty Lan } & 15 & 361.99 & 13.72 & 542.99 & 20.58 & 1733.71 & 65.70 & 2638.69 & 100.00 \\
\hline & & 30 & 271.49 & 11.12 & 452.49 & 18.53 & 1717.42 & 70.35 & 2441.40 & 100.00 \\
\hline & & 45 & 181.00 & 8.07 & 361.99 & 16.13 & 1701.13 & 75.80 & 2244.12 & 100.00 \\
\hline & & 60 & 90.50 & 4.42 & 271.49 & 13.26 & 1684.84 & 82.31 & 2046.83 & 100.00 \\
\hline & \multirow{4}{*}{ Yalova } & 15 & 361.99 & 17.27 & 542.99 & 25.90 & 1191.18 & 56.83 & 2096.15 & 100.00 \\
\hline & & 30 & 271.49 & 14.30 & 452.49 & 23.83 & 1174.89 & 61.87 & 1898.87 & 100.00 \\
\hline & & 45 & 181.00 & 10.64 & 361.99 & 21.27 & 1158.60 & 68.09 & 1701.58 & 100.00 \\
\hline \multirow{17}{*}{ III. Time } & & 60 & 90.50 & 6.02 & 271.49 & 18.05 & 1142.31 & 75.94 & 1504.30 & 100.00 \\
\hline & \multirow{4}{*}{ Bodegold } & 15 & 361.99 & 13.72 & 542.99 & 20.58 & 1733.71 & 65.70 & 2638.69 & 100.00 \\
\hline & & 30 & 271.49 & 11.12 & 452.49 & 18.53 & 1717.42 & 70.35 & 2441.40 & 100.00 \\
\hline & & 45 & 181.00 & 8.07 & 361.99 & 16.13 & 1701.13 & 75.80 & 2244.12 & 100.00 \\
\hline & & 60 & 90.50 & 4.42 & 271.49 & 13.26 & 1684.84 & 82.31 & 2046.83 & 100.00 \\
\hline & & 15 & 361.99 & 13.72 & 542.99 & 20.58 & 1733.71 & 65.70 & 2638.69 & 100.00 \\
\hline & & 30 & 271.49 & 11.12 & 452.49 & 18.53 & 1717.42 & 70.35 & 2441.40 & 100.00 \\
\hline & Dulla & 45 & 181.00 & 8.07 & 361.99 & 16.13 & 1701.13 & 75.80 & 2244.12 & 100.00 \\
\hline & & 60 & 90.50 & 4.42 & 271.49 & 13.26 & 1684.84 & 82.31 & 2046.83 & 100.00 \\
\hline & & 15 & 361.99 & 13.72 & 542.99 & 20.58 & 1733.71 & 65.70 & 2638.69 & 100.00 \\
\hline & & 30 & 271.49 & 11.12 & 452.49 & 18.53 & 1717.42 & 70.35 & 2441.40 & 100.00 \\
\hline & Zloty Lan & 45 & 181.00 & 8.07 & 361.99 & 16.13 & 1701.13 & 75.80 & 2244.12 & 100.00 \\
\hline & & 60 & 90.50 & 4.42 & 271.49 & 13.26 & 1684.84 & 82.31 & 2046.83 & 100.00 \\
\hline & & 15 & 361.99 & 17.27 & 542.99 & 25.90 & 1191.18 & 56.83 & 2096.15 & 100.00 \\
\hline & & 30 & 271.49 & 14.30 & 452.49 & 23.83 & 1174.89 & 61.87 & 1898.87 & 100.00 \\
\hline & Yalova & 45 & 181.00 & 10.64 & 361.99 & 21.27 & 1158.60 & 68.09 & 1701.58 & 100.00 \\
\hline & & 60 & 90.50 & 6.02 & 271.49 & 18.05 & 1142.31 & 75.94 & 1504.30 & 100.00 \\
\hline
\end{tabular}


the cost of harvest in total variable costs may be lower when the harvest is mechanized.

In the study, the production values were calculated separetely for different sowing times (I., II., III.), cultivars/genotype (Bodegold, Bona, Zloty Lan and Yalova) and row spacing (15, 30, 45 and $60 \mathrm{~cm})$.

According to Table 2, for all three cultivars except Yalova genotype, the total production and variable costs were found to be the highest at the row spacing of $15 \mathrm{~cm}$ in every three-sowing time. While the production cost per unit was considered the most cost was $44.62 €$ ha $^{-1}$ at third sowing time of Bodegold cultivar at $30 \mathrm{~cm}$ row spacing, the lowest one was $18.10 € \mathrm{ha}^{-1}$ at first sowing time of Zloty Lan cultivar at $15 \mathrm{~cm}$ row spacing.

When the differences among cultivars/genotypes were examined at the end of the statistical analysis; while there was no statistical significance between sowing time and total variable costs, there was significance of production cost per unit in terms of sowing times. When the cultivars/genotype were evaluated in terms of the differences on costs; the differences among total variable costs, total production costs and production cost per unit was found as statistically significant. When row spacing among groups were examined; total variable costs and total production costs were found as significance, but production costs per unit was not found significant (Table 2). While analysing gross margins; sale prices as flos chamomillae of Bodegold, Bona, Zloty Lan was $6.79 € \mathrm{~kg}^{-1}$, that of Yalova genotype was $4.53 € \mathrm{~kg}^{-1}$. The main reason of that price difference is cultivars that used as a material in this study include chamazulene inside, but Yalova population do not contain this matter. This situation results with lower selling price for Yalova genotype relatively. When the efficiency, gross production value, gross profit and net profit were examined; the maximum result for these variables was found for first sowing time of Zloty Lan cultivar at $15 \mathrm{~cm}$ row spacing. The minimum efficiency, gross profit and net profit were calculated for third sowing time of Bodegold cultivar at $30 \mathrm{~cm}$ row spacing. The minimum gross production value was $3900.45 € \mathrm{ha}^{-1}$ for third sowing time of Yalova genotype at $30 \mathrm{~cm}$ row spacing.

In the statistical analysis to identify the differences between group for yield and production value; the differences among all sowing times were found as significant (Table 3). Additionally, the statistical analysis for cultivars/genotype were also significant. According to Table 3 statistical analysis for row spacing demonstrated that just there is a significant difference for yield and no significant difference was found for gross production value, gross profit and net profit. As a conclusion, there were four cultivars/genotype, three sowing time (early November, early October, end of October) and four rows spacing $(15 \mathrm{~cm}, 30 \mathrm{~cm}, 45 \mathrm{~cm}, 60$ $\mathrm{cm}$ ) in the study and the gross margin analyses were done and the most important costs in variable expenses were found as seed cost, maintenance costs and harvesting costs. The important reason of why variable costs was important was different row spacing. As decrease the row spacing had increased both yield and maintanence costs in this study.

While other researchers (Kwiatkowski 2015) obtained the highest yield at 35 and $45 \mathrm{~cm}$ row spacing, the highest yield in our study was obtained from the lowest row spacing of $15 \mathrm{~cm}$. It is presumed that this is caused by the fact that Kwiatkowski (2015)'s study is different in sowing time (in April) and different cultural practices (different growth stimulators).

Finally, although the differences among groups were not high ratios and statistically significant, the maximum gross profit was calculated for first sowing time of Zloty Lan cultivar at $15 \mathrm{~cm}$ row spacing and the minimum one was found for third sowing time of Bodegold cultivar at $30 \mathrm{~cm}$ row spacing.

\section{Conclusions}

In this study, three of the four different types of chamomile used as material are imported. The Yalova genotype is domestic. Therefore, the seed costs of imported varieties are higher than those of the domestic genotype. As a result of the statistical 
Table 2- Variable costs, total production costs and production cost per unit for groups

\begin{tabular}{|c|c|c|c|c|c|}
\hline Sowing time & Cultivars & $\begin{array}{c}\text { Row spacing } \\
(\mathrm{cm})\end{array}$ & $\begin{array}{l}\text { Variable cost } \\
\left(€ h a^{-1}\right)\end{array}$ & $\begin{array}{l}\text { Total production cost } \\
\left(€ h a^{-1}\right)\end{array}$ & $\begin{array}{c}\text { Production cost per unit } \\
\left(€ h a^{-1}\right)\end{array}$ \\
\hline \multirow{17}{*}{ I. Time } & \multirow{4}{*}{ Bodegold } & 15 & 2638.69 & 3057.19 & 25.34 \\
\hline & & 30 & 2441.40 & 2854.03 & 30.00 \\
\hline & & 45 & 2244.12 & 2650.81 & 28.46 \\
\hline & & 60 & 2046.83 & 2447.60 & 28.14 \\
\hline & \multirow{4}{*}{ Bona } & 15 & 2638.69 & 3057.19 & 21.09 \\
\hline & & 30 & 2441.40 & 2854.03 & 22.81 \\
\hline & & 45 & 2244.12 & 2650.81 & 24.84 \\
\hline & & 60 & 2046.83 & 2447.60 & 21.13 \\
\hline & \multirow{4}{*}{ Zloty Lan } & 15 & 2638.69 & 3057.19 & 18.10 \\
\hline & & 30 & 2441.40 & 2854.03 & 25.57 \\
\hline & & 45 & 2244.12 & 2650.81 & 22.49 \\
\hline & & 60 & 2046.83 & 2447.60 & 24.48 \\
\hline & \multirow{4}{*}{ Yalova } & 15 & 2096.15 & 2498.42 & 24.07 \\
\hline & & 30 & 1898.87 & 2295.20 & 18.46 \\
\hline & & 45 & 1701.58 & 2091.99 & 22.35 \\
\hline & & 60 & 1504.30 & 1888.78 & 18.73 \\
\hline & \multirow{4}{*}{ Bodegold } & 15 & 2638.69 & 3057.19 & 20.68 \\
\hline \multirow{14}{*}{ II. Time } & & 30 & 2441.40 & 2854.03 & 23.94 \\
\hline & & 45 & 2244.12 & 2650.81 & 26.20 \\
\hline & & 60 & 2046.83 & 2447.60 & 26.24 \\
\hline & \multirow{4}{*}{ Bona } & 15 & 2638.69 & 3057.19 & 28.42 \\
\hline & & 30 & 2441.40 & 2854.03 & 27.69 \\
\hline & & 45 & 2244.12 & 2650.81 & 24.21 \\
\hline & & 60 & 2046.83 & 2447.60 & 22.35 \\
\hline & \multirow{4}{*}{ Zloty Lan } & 15 & 2638.69 & 3057.19 & 22.26 \\
\hline & & 30 & 2441.40 & 2854.03 & 27.78 \\
\hline & & 45 & 2244.12 & 2650.81 & 26.15 \\
\hline & & 60 & 2046.83 & 2447.60 & 21.22 \\
\hline & \multirow{4}{*}{ Yalova } & 15 & 2096.15 & 2498.42 & 24.25 \\
\hline & & 30 & 1898.87 & 2295.20 & 26.47 \\
\hline & & 45 & 1701.58 & 2091.99 & 21.18 \\
\hline \multirow{17}{*}{ III. Time } & & 60 & 1504.30 & 1888.78 & 19.28 \\
\hline & \multirow{4}{*}{ Bodegold } & 15 & 2638.69 & 3057.19 & 37.29 \\
\hline & & 30 & 2441.40 & 2854.03 & 44.62 \\
\hline & & 45 & 2244.12 & 2650.81 & 33.35 \\
\hline & & 60 & 2046.83 & 2447.60 & 37.33 \\
\hline & \multirow{4}{*}{ Bona } & 15 & 2638.69 & 3057.19 & 27.60 \\
\hline & & 30 & 2441.40 & 2854.03 & 33.85 \\
\hline & & 45 & 2244.12 & 2650.81 & 39.00 \\
\hline & & 60 & 2046.83 & 2447.60 & 32.62 \\
\hline & \multirow{4}{*}{ Zloty Lan } & 15 & 2638.69 & 3057.19 & 28.73 \\
\hline & & 30 & 2441.40 & 2854.03 & 25.38 \\
\hline & & 45 & 2244.12 & 2650.81 & 22.31 \\
\hline & & 60 & 2046.83 & 2447.60 & 25.75 \\
\hline & \multirow{4}{*}{ Yalova } & 15 & 2096.15 & 2498.42 & 22.94 \\
\hline & & 30 & 1898.87 & 2295.20 & 26.61 \\
\hline & & 45 & 1701.58 & 2091.99 & 23.67 \\
\hline & & 60 & 1504.30 & 1888.78 & 20.45 \\
\hline
\end{tabular}


Table 3- Yield, gross production value, gross profit and net profit values for groups

\begin{tabular}{|c|c|c|c|c|c|c|}
\hline Sowing time & Cultivars & $\begin{array}{c}\text { Row spacing } \\
\text { (cm) }\end{array}$ & $\begin{array}{c}\text { Yield } \\
\left(\text { ton } h a^{-1}\right)\end{array}$ & $\begin{array}{l}\text { Gross production value } \\
\left(€ h a^{-1}\right)\end{array}$ & $\begin{array}{l}\text { Gross profit } \\
\quad\left(€ h a^{-1}\right)\end{array}$ & $\begin{array}{l}\text { Net profit } \\
\left(€ h a^{-1}\right)\end{array}$ \\
\hline \multirow{17}{*}{ I. Time } & \multirow{4}{*}{ Bodegold } & 15 & 1.21 & 8192.31 & 5553.62 & 5135.11 \\
\hline & & 30 & 0.95 & 6454.75 & 4013.35 & 3600.72 \\
\hline & & 45 & 0.93 & 6325.79 & 4081.67 & 3674.98 \\
\hline & & 60 & 0.87 & 5904.98 & 3858.14 & 3457.38 \\
\hline & \multirow{4}{*}{ Bona } & 15 & 1.45 & 9848.42 & 7209.73 & 6791.22 \\
\hline & & 30 & 1.25 & 8497.74 & 6056.33 & 5643.71 \\
\hline & & 45 & 1.07 & 7242.08 & 4997.96 & 4591.27 \\
\hline & & 60 & 1.16 & 7866.52 & 5819.68 & 5418.91 \\
\hline & \multirow{4}{*}{ Zloty Lan } & 15 & 1.69 & 11457.01 & 8818.33 & 8399.82 \\
\hline & & 30 & 1.12 & 7581.45 & 5140.05 & 4727.42 \\
\hline & & 45 & 1.18 & 7995.48 & 5751.36 & 5344.66 \\
\hline & & 60 & 1.00 & 6787.33 & 4740.50 & 4339.73 \\
\hline & \multirow{4}{*}{ Yalova } & 15 & 1.04 & 4692.31 & 2596.15 & 2193.89 \\
\hline & & 30 & 1.24 & 5628.96 & 3730.09 & 3333.76 \\
\hline & & 45 & 0.94 & 4235.29 & 2533.71 & 2143.30 \\
\hline & & 60 & 1.01 & 4561.09 & 3056.79 & 2672.31 \\
\hline & \multirow{4}{*}{ Bodegold } & 15 & 1.48 & 10031.67 & 7392.99 & 6974.48 \\
\hline \multirow{14}{*}{ II. Time } & & 30 & 1.19 & 8090.50 & 5649.10 & 5236.47 \\
\hline & & 45 & 1.01 & 6861.99 & 4617.87 & 4211.18 \\
\hline & & 60 & 0.93 & 6332.58 & 4285.75 & 3884.98 \\
\hline & \multirow{4}{*}{ Bona } & 15 & 1.08 & 7303.17 & 4664.48 & 4245.97 \\
\hline & & 30 & 1.03 & 6990.95 & 4549.55 & 4136.92 \\
\hline & & 45 & 1.10 & 7432.13 & 5188.01 & 4781.31 \\
\hline & & 60 & 1.10 & 7438.91 & 5392.08 & 4991.31 \\
\hline & \multirow{4}{*}{ Zloty Lan } & 15 & 1.37 & 9325.79 & 6687.10 & 6268.60 \\
\hline & & 30 & 1.03 & 6970.59 & 4529.19 & 4116.56 \\
\hline & & 45 & 1.01 & 6875.57 & 4631.45 & 4224.75 \\
\hline & & 60 & 1.15 & 7827.15 & 5780.32 & 5379.55 \\
\hline & \multirow{4}{*}{ Yalova } & 15 & 1.03 & 4660.63 & 2564.48 & 2162.22 \\
\hline & & 30 & 0.87 & 3923.08 & 2024.21 & 1627.87 \\
\hline & & 45 & 0.99 & 4466.06 & 2764.48 & 2374.07 \\
\hline \multirow{17}{*}{ III. Time } & & 60 & 0.98 & 4429.86 & 2925.57 & 2541.09 \\
\hline & \multirow{4}{*}{ Bodegold } & 15 & 0.82 & 5565.61 & 2926.92 & 2508.42 \\
\hline & & 30 & 0.64 & 4343.89 & 1902.49 & 1489.86 \\
\hline & & 45 & 0.80 & 5395.93 & 3151.81 & 2745.11 \\
\hline & & 60 & 0.66 & 4452.49 & 2405.66 & 2004.89 \\
\hline & \multirow{4}{*}{ Bona } & 15 & 1.11 & 7513.57 & 4874.89 & 4456.38 \\
\hline & & 30 & 0.84 & 5721.72 & 3280.32 & 2867.69 \\
\hline & & 45 & 0.68 & 4615.38 & 2371.27 & 1964.57 \\
\hline & & 60 & 0.75 & 5090.50 & 3043.67 & 2642.90 \\
\hline & \multirow{4}{*}{ Zloty Lan } & 15 & 1.06 & 7221.72 & 4583.03 & 4164.52 \\
\hline & & 30 & 1.13 & 7635.75 & 5194.34 & 4781.72 \\
\hline & & 45 & 1.19 & 8063.35 & 5819.23 & 5412.53 \\
\hline & & 60 & 0.95 & 6454.75 & 4407.92 & 4007.15 \\
\hline & \multirow{4}{*}{ Yalova } & 15 & 1.09 & 4932.13 & 2835.97 & 2433.71 \\
\hline & & 30 & 0.86 & 3900.45 & 2001.58 & 1605.25 \\
\hline & & 45 & 0.88 & 4000.00 & 2298.42 & 1908.01 \\
\hline & & 60 & 0.92 & 4176.47 & 2672.17 & 2287.69 \\
\hline
\end{tabular}


analysis, it is meaningful that significant differences were found between product and total variable costs. The reason for the high gross profit and net profit obtained from the import varieties used as the material in the study is that the selling price of the product is higher than the domestic genotype. The fact that imported varieties can be sold at 50\% more price than the Yalova genotype is the most important reason for this difference. This result supports the fact that the difference between the groups in terms of yield and production values is significant in terms of statistical analysis.

\section{References}

Bayram E, Kırıc1 S, Tansı S, Y1lmaz G, Arabac1 O, Kızıl S \& Telci İ (2010). Tibbi ve aromatik bitkiler üretiminin arttırılması olanakları, TMMOB Ziraat Mühendisleri Odası Ziraat Mühendisliği VII. Teknik Kongresi Bildiriler Kitabı 1, 11-15 Ocak 2010, Ankara, s. 437456

Ceylan A (1996). Tıbbi Bitkiler II (Uçucu Yağ Bitkileri), Ege Üniversitesi Ziraat Fakültesi, Yayın No: 481, 306 s

Gül G (1995). Matricaria chamomilla L. var. recutita Grierson üzerinde farmakognozik araştırmalar, Yüksek lisans tezi, T.C. Gazi Üniversitesi Sağlık Bilimleri Enstitüsü, Ankara, $96 \mathrm{~s}$

Güngör F U, Bayraktar N \& Kaya M D (2005). Geliştirilmiş İzmir Kekiği (Origanum onites L.) Klonlarının kula şartlarında tarımsal ve kalite yönünden karşılaştırılması, Tarım Bilimleri Dergisi 11(2): 196-200

Ivanović S, Pajić M \& Marković T (2014). Economic effectiveness of mechanized harvesting of chamomile, Economics of Agriculture 2/2014 EP 2014 61(2): 319330

Johri A K, Srivastava L J, Singh J M \& Rana R C (1991). Effect of row spacings and nitrogen levels on flower and essential oil yield in German Chamomile (Matricaria chamomilla L.), Indian-Perfumer 35(2): 93-96

Karagölge C (2001). Tarımsal İşletmecilik-Tarım İşletmelerinin Analizi ve Planlanması, Atatürk Üniversitesi Yayınları, No: 827, Ziraat Fakültesi Yayınları No: 326, Ders Kitabı: 74, Erzurum

Kruskal W H \& Wallis W A (1952). Use of ranks in onecriterion variance analysis, Journal of The American Statistical Association 47: 583-621

Kwiatkowski C A (2015). Yield and quality of chamomile (Chamomilla recutita (L.) Rausch.) raw material depending on selected foliar sprays and plant spacing. Acta Scientiarum Polonorum, Hortorum Cultus 14(1): $143-156$

Salamon I (2004). The Slovak gene pool of German Chamomile (Matricaria recutita L.) and comparison in its parameters, Horticultural Science (Prague) 31(2): 70-75

Stričík M \& Salamon I (2007). Investment rating with a combine harvester acquisition for Chamomile Flower Picking. In: I. Salamon (Editor), I International Symposium on Chamomile Research, Development and Production, 31.08. 2007. ISHS Acta Horticulturae. 